e-ISSN: 2623-0089

Website :

jurnal.umj.ac.id/index.php/baskara

Email : baskara@umj.ac.id

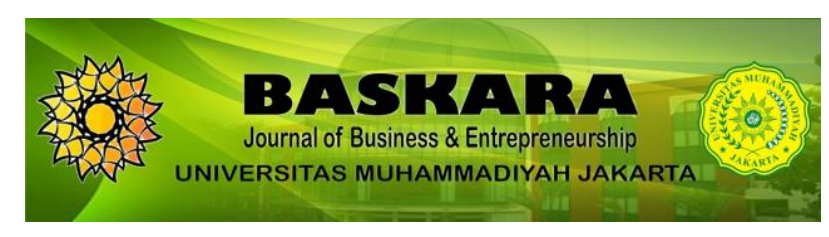

\title{
The Bureaucracy Neutrality in Indonesian Politics
}

\author{
R. Siti Zuhro \\ Lembaga Ilmu Pengetahuan Indonesia: LIPI \\ Jl. Gatot Subroto 10, Daerah Khusus Ibukota Jakarta 12710 \\ E-mail:rszuhro@gmail.com
}

\begin{abstract}
The politicization of the Indonesian bureaucracy in the election is attracting great attention since it's resulted in the declining quality of democracy in this country. Although political change since 1998 has given greater strength to societal forces vis-à-vis the state, the fact is that the legacy of the patronage network still exists. An important stimulus for this study was the politicization of the bureaucracy through the weakening of political parties and maintaining bureaucratic authoritarianism under the New Order government (1966-1998). With the downfall of Soeharto's New Order regime, the authoritarian nature of the bureaucratic system was not only exposed but also changed. These changes have put paid to questions about the involvement of political parties and the influence of societal forces in the formation of policy. The bureaucracy can no longer exist as it was in the New Order, and, in fact, has responded to societal needs by adjusting to the new political climate. In this context, Indonesian politics under the reformation era takes on a wider significance for one of the main results has been the emergence of bureaucratic pluralism - a more pluralistic political system that is more open to the influence of these societal forces. This study was conducted using a literature review to understand theories and empirical experiences about the neutrality of the bureaucracy in both national elections and regional elections. This study showed that after 75 years of independence, Indonesia must continue to struggle to build a bureaucracy that is professional (effective and efficient) and politically neutral.
\end{abstract}

Keywords: Bureaucracy, Politics, Societal Forces, Election

\section{INTRODUCTION}

After the fall of the New Order, 1998, the issue of bureaucracy and democracy has become a central issue and public debate. The crucial issue of this bureaucratic reform cannot be separated from the increasingly strong demands of the people so that the bureaucracy will become 'servant of the people'. It is difficult to deny that the poor quality of the bureaucracy is one of the sources of Indonesia's backwardness. Even though Indonesia's per capita income in 2010 rose to $\$ 3,500$ dollars, Indonesia's ranking was still below Brunei (\$51,000),
Singapore (\$49,700), Malaysia (\$ 13.300), and Thailand (\$ 7,900). Apart from infrastructure problems and corruption, bureaucracy has become one of the obstacles to development.

In a democratic political system, the bureaucracy is not involved in politics. The bureaucracy has positioned itself as a professional and neutral institution instead (Asmeron and Reis, 1996). From a macro perspective, it can be concluded that democracy and bureaucracy are interrelated (Etzioni-Halevy, 1985). The process of democracy (democratization) currently 
taking place is expected to be able to encourage bureaucratic reform. On the other hand, bureaucratic reform is also expected to strengthen democratization. A reformed bureaucracy will make itself neutral, more transparent, accountable and aspirational. Such a bureaucratic model will not only have a positive effect on bureaucratic relations and society, but also politics and elections.

\section{The Concept of Neutrality and Public Bureaucracy}

The neutrality of the bureaucracy in elections is a crucial issue that always arises in every election. Developed and democratic countries such as Britain, United States and France, their bureaucracies are not involved in politics. Because the bureaucracy places itself as a professional and neutral institution (Asmeron and Reis, 1996). Democracy and bureaucracy are interrelated (EtzioniHalevy, 1985). It is hoped that the democratization that has been taking place in Indonesia since 1998 will encourage bureaucratic reform. On the other hand, it is also hoped that reform of bureaucracy will strengthen democratization. A reformed bureaucracy will make itself neutral, participative, transparent and accountable. Such a bureaucratic model will affect the relationship between bureaucracy and society. In the context of elections, bureaucratic neutrality in national elections / regional election.

Elections are one of the important pillars of democracy. One of the elections' success is related to the bureaucracy. So far, empirical experience shows that bureaucracy cannot be separated from politics, especially in elections. The neutrality of the bureaucracy, for example, is difficult to achieve because of political intervention in the bureaucracy (Zuhro, 2019c).

The history of Indonesian politics shows that the bureaucracy has not been placed in its position, function and role as an organization that governs the country in a professional manner. This can be traced from the pre-Dutch colonial era to the era of Soeharto's New Order. New Order era, for example, the bureaucracy always supported Golkar in every election (Zuhro, 2005). Furthermore, the bureaucracy is also used as a tool of interest for the authorities to maintain their power. The role of the bureaucracy is very prominent, followed by the weakening of the political parties and parliament's role. The centralization of power is fully supported by an authoritarian bureaucratic system. Politically, the bureaucracy is used as a builder for political parties. Economically, the bureaucracy is used to support the course of national economic development. As a result, the democratic process is hampered, where people's awareness of political rights is low and political parties do not play a role as political parties in democratic countries (Zuhro, 2005).

Under these conditions, Indonesia in the New Order era was classified as a relatively developed country economically but politically backward. However, the assumptions about economic progress are not entirely correct, because the monetary and economic crises that hit Indonesia concretely prove that Indonesia's economic fundamentals were not strong enough to withstand the impact of the crisis that took place during the 1997-1998 period. This phenomenon shows that economic development that was not followed by political development (during the New Order) resulted in the fragility of democratic institutions.

The representative democracy system adopted since 1971-2003, which prioritized the legislative role in the electoral process, has had its own impact on political development. With such a representative system, the process and mechanism for selecting leaders only takes place within the People's Consultative Assembly for the national and Assembly at Regional for the regions. In other words, society is not 
involved in the election of leaders, and society is only the object of politics and the interest target of political parties.

On the other hand, in the direct election model, community participation is necessary. It is hoped that these processes and mechanisms will have a positive impact on the empowerment of the people. A more real impact will also be felt in the form of increased public political awareness and participation. By means of that case, the people are expected to be more capable of responding to public policies made by the government.

Meanwhile, in the bureaucracy sector, Indonesia is classified lagging behind Singapore, Malaysia and Thailand. The bureaucracy in the three countries has entered a professional and innovative stage both from the services perspective (especially Singapore) and the neutrality in politics. Indonesia was once dubbed a "bureaucratic polity" country, because the public policy process was only determined by the civilian and military bureaucrat elites (Jackson, 1978). In addition, Indonesia has also been dubbed a "bureaucratic authoritarian" and "bureaucratic patrimonialism" referring to the patronclient system, both in the decision-making and in its implementation (Crouch, 1971; King 1982). Bureaucratic authoritarian is marked by the relatively strong position of the state when dealing with elite factions supporting it and civil society. The strong oversight by the bureaucratic authoritarian state towards civil society is intended to prevent the masses from becoming involved in politics, so that the development process is not disturbed. As a result, the state grows into a repressive, bureaucratic and technocratic political force. During its development, the Indonesian bureaucracy is still colored by a system of patrimonialism or patronage which is full of patron-client relationships.

A bureaucratic system which is not transparent and closes people's access to participate in the policy-making process, makes the bureaucracy unresponsive to people's participation. Not a few of public policies made by the government only benefit certain parties or groups and deny the aspirations and the wider community's interests. Starting from this, the 1998 reform movement, for example, wanted to improve the performance of the bureaucracy with a focus on eradicating corruption, collusion and nepotism in the bureaucracy. Shortly after this reform movement, there was also a "bureaucratic neutrality movement" initiated by Indonesia University's medical students and later expanded to be followed by the Ministry of Information by dissolving the Indonesian Civil Service Corps, and explicit statements of Forestry Department civil servants who supported bureaucratic neutrality. Likewise, several statements were made by the chairman of the Central Indonesian Civil Service Corps, Feisal Tamin, which basically supported the neutrality of the bureaucracy (Zuhro, 2005).

The bureaucratic neutrality movement can be interpreted as a demand to reform the bureaucracy. The goal is that the bureaucracy can improve its quality in serving the state and society. In addition, the bureaucracy can be neutral in every national election and regional election. This effort is intended so that the bureaucracy is able to carry out its functions professionally. In the context of elections, it is hoped that the professional and neutral bureaucracy will have a positive influence on the realization of quality elections. Direct election is the first to be held in Indonesian political history. Since the first election (1999) after the fall of the New Order, there have been 5 national elections held. At the local level, there were more than 1500 direct elections for provinces, regencies / cities that were held during 2005-2018. Five elections that took place (1999, 2004, 2009, 2014 and 2019), show the issue of bureaucratic involvement and money politics is a permanent issue. It is increasingly difficult to prevent the involvement of the 
bureaucracy in elections. Especially if the incumbent candidate participates in the election / regional election competition.

The problem is that the involvement of the bureaucracy in elections tends to be increasingly difficult to eliminate. Although the involvement of the bureaucracy was relatively lacking, especially in the 1999 elections, this involvement has strengthened again since the direct presidential election (2004). It shows the inconsistency of the bureaucracy in maintaining its position as a neutral and independent institution. It reinforces the argument that the relatively neutrality of the bureaucracy in the 1999 election was only an adaptation of the bureaucracy to the political climate of openness at that time. The long history of bureaucratic involvement in politics makes it vulnerable and becomes an arena for conflict of political parties' interests. For example, even before the enactment of Law no. 5 of 2014 (concerning the State Civil Apparatus) there have been PP 5/1999 and 12/1999 concerning Civil Servants which prohibit the Civil Servants from becoming officials of political parties, it does not mean that the bureaucracy can automatically be neutral and professional. It is clear that it is difficult to expect change from within the bureaucracy itself, without strong pressure and demands from non-bureaucratic forces (social forces). Therefore, the role of social forces in encouraging change or improvement of the bureaucracy is really needed, especially to maintain the neutrality of the bureaucracy in elections.

Neutrality is a popular concept which according to Webster's dictionary means "not engaged on either side, not aligned with a political or ideological grouping, not decided or pronounced as to characteristics". Neutrality is related to several indicators such as keeping distance, not being involved, being impartial, and not differentiating the existing political groups or parties. In other words, neutrality refers to an objective, neutral attitude that does not favour one particular party.

The modern and rational concept of bureaucracy adopted by many developed countries so far cannot be separated from Weber's idea that views bureaucracy as " $a$ hierarchical organisation of officials appointed to carry out certain public objectives. It is the institution that carries out the functions and responsibilities of government" (1947:150). Bureaucracy is related to civil servants or bureaucrats who run the bureaucracy. In this study, civil servants refer to staff at the central and regional levels which are state administrative regions. Ideally, in a democratic country, "civil servants devote their lives to the service of the community" (Gladden, 1956:17-18). Therefore, in their role as professional staff, civil servants treat politicians and political parties equally, basing their policies on objective judgments. Once government determines its policy, civil servants implement the policy without having to be influenced by the interests of the ruling or opposition parties. It shows that the political neutrality of civil servants refers to the attitude of civil servants who can express their siding with certain political parties during elections, but not when carrying out their duties in the bureaucracy (Asmerom and Reis, 1996:4).

The argument of Asmerom and Reis (1996) is also supported by Fisher and Lundgreen (1975) who say that: A modern civil service is defined as a corps of specifically trained, examined and appointed men, independent from political conjuncture, impartial in discharging their services, fully salaried and pensioned by the state and fully employed by it, subject to hierarchical order in which they move upward according to seniority or merit or a mixture of both (Fisher and Lundgreen, 1975:459). Fisher and Lundgreen's statement (1975) clearly shows that civil servants should be professional in carrying out their duties as public servants and be politically neutral in legislative / 
presidential and regional elections. In addition, civil servants also have the right to receive adequate salaries so that they can be professional and not partisan in carrying out their duties.

For Weber, who introduced the concept of bureaucracy as reflected in his idea of power, domination and authority, modern and rational bureaucracies are seen as the most efficient than patrimonial administration. This is because modern bureaucracy is considered as "a legitimate exercise of power because of its power to regulate, be predictable and adhere to impersonal rules." This is what distinguishes it from the patrimonial administration system which does not consider the idea of bureaucratic professionalism and tends to recruit employees in a closed manner and relies on collusion.

In his classic article Crouch (1979:572) stated that the modernization that took place in Indonesia in the 1970s resulted in new challenges for the government and at the same time a threat to government stability. During the 1970-1990 period, economic changes have resulted in social groups and classes in society who have different political interests. Demands on government capacity to meet community needs are also increasing.

Crouch (1979) also argued that during the Guided Democracy and New Order periods, for example, there were many depictions of the political system returning to patrimonialism. Although Crouch's writing was published in 1979, his ideas are still relevant for analyzing Indonesian politics in the transitional era, especially his argument about "the coexistence of patrimonialism with modernization". Indonesia since 1998 is an example of a society that has undergone economic, social and political changes, but still exhibits some traditional characteristics. According to Chalmers (1998:70-71), until 1998, Indonesia's political culture was patrimonial, where the decision-making process was very top-down and all important decisions had to be approved by the president for ratification.

From the description above, it is clear that the ideal bureaucracy is one that is not patrimonial and the civil servants are neutral. In other words, civil servants are able to demonstrate their capacity to work professionally and as government officials who provide public services and are neutral in state affairs.

The issue of democratization and bureaucratic reform is a debate that is almost never finished in the development of Indonesian politics. In reality, bureaucracy and democracy influence each other. The strength of state intervention in the economic sector in the New Order era made the role of the bureaucracy even bigger. The large role of the bureaucracy makes it more likely to be politicized. As a result, the bureaucracy is almost never neutral in its actual meaning, and even fails to carry out its duties to serve the community because the bureaucracy is increasingly unprofessional and tends to side with the interests of the authorities. This makes the Indonesian bureaucracy tendentiously partisan.

One important key to the success of elections lies in the neutrality of civil servants / state civil apparatus / bureaucracy. In many national and regional elections, state civil apparatus' position is very strategic, making it vulnerable to politicization. With such a position, concrete support from the government is needed in the form of political will, political commitment, and law enforcement. Improving bureaucracy through improving the pattern of its relations with politics and society is needed so that this relationship produces synergies that can mutually empower, not subordinate each other. The greater the neglect of the bureaucracy and political power towards citizens, the greater the tendency for political collaboration between the bureaucracy, political parties and entrepreneurs/capital forces to be 
opportunistic in nature. Therefore, it is necessary to apply a functional relationship pattern (who does what) between the bureaucracy, political power, and society so that their relationship is not biased or even denies the existence of society.

\section{RESEARCH METHODS}

In this context, the study of whether or not the bureaucracy is neutral in elections is very important because the Indonesian people want to realize good governance, eliminate corruption, collusion and nepotism, and demand an accountability system so that government tasks can be accountable to the people. These issues arise in line with the emergence of issues regarding socio-economic inequality and social justice that are increasingly spreading in society. Furthermore, the emergence of several of these issues cannot be separated from the growing number and role of societal forces in society since the 1998 reform movement. It is hard to deny that these social forces in society have promoted the importance of participation and pluralism. In other words, the role of civil society in encouraging bureaucratic reform and democracy is increasingly important, because the creation of good governance cannot be expected solely from the government.

This bureaucratic neutrality study was carried out through a literature review to understand the theory and practice of bureaucratic neutrality related to elections held at the national level and regional elections held in regions in Indonesia using literature as an instrument to obtain data.

\section{RESULT AND DISCUSSION}

After 75 years of independence, Indonesia must continue to struggle to build a bureaucracy that is professional (effective and efficient) and politically neutral. As the big wheel of national and regional development, the bureaucracy must not be vulnerable to political intervention. Moreover, it is only oriented for short-term interests, for certain parties / groups / individuals. The State Civil Apparatus is "state servant" and "public servant" who is obliged to work for the country's advancement and benefit. Because it is not justified if the bureaucracy is intervened by political forces to perpetuate its power. In principle, the change of leadership at both the central and regional levels that takes place every 5 years should not damage the bureaucratic structure. On the other hand, elections should be positively correlated or have a positive impact on good governance. This is important to realize the people's progress and welfare.

Here are the bureaucratic dynamics from period to period.

\section{B.J. Habibie's Era (1998-1999)}

1. Bureaucratic reform and eradication of corruption, collusion and nepotism

2. Civil servants must be neutral in politics (PP 12/1999)

3. The election in 1999, civil servants do not have to support Golkar

4. The stipulation of the Basic Civil Service Act (UU 43/1999)

\section{Abdurrahman Wahid's Era (1999-2001)}

1. Bureaucratic reform and eradication of corruption

2. Combined Corruption Eradication Team (forerunner to the Corruption Eradication Commission)

3. Enforcement of minus growth policies for civil servants

\section{Megawati's Era (2001-2004)}

1. Bureaucratic reform and eradication of corruption

2. Legal products: Anti-Corruption Commission, guidelines for procurement of goods and services in agencies.

\section{SBY's Era (2004-2009, 2009-2014)}

1. Eradication of corruption.

2. Structural reform of the bureaucracy and the quality improvement of public 
services through the public service innovation system which began in 2014 and is implemented annually by the Ministry of State Apparatus Empowerment and Bureaucratic Reforms. The public innovation competition is participated by ministries, institutions and local governments (province, district and city).

3. Presidential regulations related to the grand design and road map for bureaucratic reform 2010-2025.

4. Support from the central (House of People's Representatives) and regional (Assembly at Regional) legislatures has not been maximal and the reform initiatives in government institutions have been slow.

5. The performance of the regional bureaucracy is still not optimal even though decentralization and regional autonomy have been implemented.

6. Bureaucratic reform is not focused yet: politically, a neutral bureaucracy in the regions is expected to support an honest, fair, participatory regional election process; and economically, can increase competitiveness.

\section{Joko Widodo's Era (2014-2019)}

1. Support from the central (House of People's Representatives) and regional (Assembly at Regional) legislatures is still low.

2. Reform initiatives in government institutions have not been substantive even though the action of echeloning improvement has been carried out through trimming the echelon 3 and 4 (functional positions prioritized rather than the structural ones) and the dissolution of a number of institutions deemed ineffective.

3. The performance of the regional bureaucracy is still not optimal in supporting the implementation of decentralization and regional autonomy.

4. Bureaucratic reform has not become the main focus: politically, a neutral bureaucracy at the central and regional levels is expected to support an honest, fair, participatory election / regional election process; and economically can increase competitiveness.

5. Corruption, which is a reflection of political and bureaucratic scope, is becoming more and more intense.

6. A weak leadership and a lack of commitment to bureaucratic reform have caused a decline in Indonesian bureaucracy's quality.

7. The involvement of the bureaucracy in politics is getting stronger in national elections and regional ones.

The first period of Jokowi's administration (2014-2019) had little effect on improving the bureaucracy. Even as an incumbent that participated in the 2019 presidential election competition, the bureaucracy is in a dilemma. It is difficult to argue that the political pull on the bureaucracy is very strong. The 2019 election was suspected of being an election that involved the bureaucracy, from the central to the regions. Head of district in Makassar stated his support for Jokowi publicly which cause the warning from South Sulawesis's Governor. It has made the issue of bureaucratic neutrality highlighted by the public because bureaucracy is considered partisan. The bureaucracy is very vulnerable to being used as a tool for political interests. The alignment of the bureaucracy to a certain political force creates its own vulnerability. The involvement of ministries / agencies / local governments in the winning team for candidate pairs in the presidential election, for example, has an impact on the bureaucracy, particularly on the quality of public services.

Empirical experience shows that since the presidential elections (2004) and regional elections (2005) directly elected by the people, the central to the regional bureaucracy has been difficult to be politically neutral. In fact, there are many 
cases of the use of bureaucratic facilities both at the central and regional levels that are used to win certain candidates in elections / regional elections. The use of regional budgets to win certain candidates is also difficult to avoid due to the intense politicization of the bureaucracy. Political and bureaucratic conflicts are often found, both in the time of and after the national / regional elections. Until March 2019, Bawaslu receives 165 reports on the State Officials neutrality's violation.

The irregularity of the bureaucracy in elections can result in weak legitimacy for the performance of the government, election administrators and the outcome. So far, the empirical level shows that there is a political pull, in particular, from the authorities to the bureaucracy. It seems very strong. One of them is the existence of a viral video showing the alleged support of the sub-district head in Makassar for the candidate pair Joko Widodo - Ma'ruf Amin. The politicization of the bureaucracy is increasingly evident with the making of ministers, heads of institutions, regional heads as candidate pairs in the presidential election. It is clear that the bureaucracy is involved in practical politics, not only at the centre, but also to the regions. Allegations of bureaucratic irregularity are also suspected in connection with a number of cases of multiple voters and the presence of a number of foreign nationals who have entered the voter list.

The examples of deviations in the function of the bureaucracy show the importance of reforming the bureaucracy. Ideally, the process of democracy and bureaucratic improvement should run simultaneously and complement each other. In other words, the change in the political system from an authoritarian system to a democratic one should be able to show significant improvements and changes to politics and bureaucracy, including the electoral bureaucracy.

Apart from that, despite the State Civil Apparatus Law and policies related to bureaucratic reform (such as open recruitment), in fact the Indonesian bureaucracy is still not free from patrimonial bureaucracy model, that is a bureaucratic system characterized by patron-client full of power culture, moral hazard, and safety-first philosophy. In a multi-party system that has been going on since 1999, the bureaucracy in Indonesia seems not to be neutral yet due to the many political penetrations into the bureaucracy. Corruption keeps existing, and it is even increasingly spreading to the regions. Ironically, there is almost no day without news of corruption.

This representation shows that the neutrality of the bureaucracy - especially in strengthening the political rights of civil servants / state civil apparatus and the equality of political parties - is a major challenge that must be addressed in order to build a healthier democratic climate. One of them is to separate politics from an administration career (public service) in government and public service depoliticization. Based on Asmerom and Reis, politics and policy are separated from administration; public servants are appointed and promoted on the basis of merit rather than on the basis of party affiliation or contributions; public servants do not engage in partisan political activities; public servants do not express publicly their personal views on government policies or administration; public servants provide forthright and objective advice to their political masters in private and confidence. In return, political executives protect the anonymity of public servants by publicly accepting responsibility for departmental decisions (Asmerom and Reis, 1996).

In general, the pattern of relations between the bureaucracy and politics tends to be dynamic, especially when the political process takes place, that is when the bureaucracy and politics are in the process of drafting laws and regional regulations. The intensity of relations also occurs when the bureaucracy runs its programs and when 
political institutions supervise. The balance pattern of relations between politics and bureaucracy affects the development process, both at the central and regional levels.

So far, Indonesia's experience shows that political and bureaucratic relations are characterized by characteristics such as the practice of lobbying to seek positions and political intervention in determining positions and political budget. The reform era has produced very pragmatic politicians who often carry out political manoeuvres in a corridor that violates democratic values. Many politicians use their positions and powers for their personal and group interests. Meanwhile, the bureaucracy is not quite ready to face the very dynamic political manoeuvres of politicians, so that the bureaucracy ended up trapped in "unfaithfulness" that betrays the people.

The bureaucratic and political relations as described show the strong political motives in the bureaucracy. The politicization of the bureaucracy in the regional elections, for example, has torn the solidity of the bureaucracy which has resulted in the division of civil servants. The regional head as a civil servant / bureaucracy coach in the region uses the bureaucracy as a tool to realize political interests. The neutrality of civil servants is pawned in the regional elections because they face a dilemma: both supporting and not supporting are wrong. Not a few civil servants were dismissed after the regional elections because they did not support the regional heads. Regional heads, for example, can act freely against the bureaucracy. They even can also "play" the bureaucracy such as making transfers, recruiting and installing trusted people, and utilizing all bureaucratic instruments for short-term political interests.

The bureaucracy even can be used as a political force because it has a network structure to the community base, controls adequate information, and has the authority to execute programs and budgets. The existence of the bureaucracy can be used for public interest, but at the same time it can also be used for certain political motives. It makes the bureaucracy tends to be a tool to gain and maintain power.

In the perspective of democracy and bureaucracy, the 2019 Election did not only lose its quality and integrity, but also fought the spirit of the 1998 reform movement which wanted to uphold good governance. The 2019 election should have been free and fair, the bureaucracy was not partisan, the reality was that it clearly used bureaucracy to win the presidential election. Considering the hierarchical nature of the bureaucracy, the use of bureaucratic machines to win the presidential election is very effective. Therefore, it is logical if public resistance arises against the issue of using the bureaucracy. Besides being considered violating the law, these actions are also considered to violate the bureaucratic ethics or government ones.

In many national and regional elections, the position of civil servants / state civil apparatus is very strategic so that they are vulnerable to be politicised. For this reason, the concrete support from the government is needed in the form of political will, political commitment, and law enforcement. Bureaucracy improvement through improving the pattern of relations with politics and society is needed so that these relationships produce synergies that can power each other, not mutually subordinate. The greater the neglect of the bureaucracy and political power towards citizens, the greater the tendency for political collaboration between the bureaucracy, political parties and entrepreneurs / capital forces to be opportunistic in nature. Therefore, it is necessary to apply a functional relationship pattern (who does what) between the bureaucracy, political power, and society so that their relationship is not one-sided, denying the existence of society.

Up to now, a more balanced pattern of relations between politics and the 
bureaucracy has not been developed. It means that there is no balance of relations based on clarity and balance between the roles and responsibilities of each as an institution. Political and bureaucratic relations need to be placed in a pattern that refers to relatively equal and balanced relations. This is because the bureaucracy is not just an entity that becomes an instrument or tool for implementing public policy. For Indonesia, the bureaucracy is the wheel that carries out development.

Public concern for a partisan bureaucracy is not excessive because this institution is very vulnerable and easily becomes a conflict area pf of political parties' interests. The problem of bureaucratic neutrality was being questioned again when there was an issue of mobilizing employees in state-owned enterprise, ministries and institutions and local governments to support certain candidates in the 2019 election. It certainly violates the State Civil Apparatus Law and the Election Law which prohibit involving state officials, both structural and functional. In addition, the regional elections which were simultaneously held on December 9, 2020 , not only caused a controversy in the community because it was considered to endanger the lives of residents with the Covid-19 virus, but also caused an anger for Ministry of Empowerment of State Apparatus and Bureaucratic Reforms and also State Civil Apparatus Commission towards the tendency to use bureaucracy to win the candidates. In the Webinar on Neutrality and Vigilance of State Civil Apparatus Politicization in the 2020 Regional Elections which were simultaneously held on August 10, 2020, Minister of Empowerment of State Apparatus and Bureaucratic Reforms stated: "The neutrality of the state civil apparatus in the implementation of regional elections must be upheld and monitored carefully, so that the process of implementing regional elections and administering public services can run well. Minister Tjahjo also hopes that the 2020 regional elections which were simultaneously held along with the Covid19 pandemic can be carried out by applying ethics in politics and not forgetting to keep disciplined in implementing health protocols".

This phenomenon clearly proves that the laws and regulations on State Civil Apparatus are still not strong enough to prevent the attempts to divert the function of the bureaucracy. The tendency of bureaucrats and the governing party (whatever their party) using the bureaucratic machine as an effective tool to get vote in national / regional elections seems difficult to prevent.

Opportunities for future bureaucratic reform may be hampered by conflicts of interest that never fail to use bureaucratic machines to get votes in elections, both through hidden ways or implicit statements by officials. Moreover, in the era of direct regional elections that have simultaneously taken place since 2015, the regional bureaucracy has become increasingly difficult to be professional.

Apart from the big challenges that the bureaucracy still faces to become professional, neutral, accountable and participatory, in general it can be said that the bureaucracy reform era tends to create a plural bureaucracy characterized by an increasingly plural political system in which this system is more opened to the influence of societal forces in society. One of the important indicators of the bureaucratic pluralism's characteristics is that none of the public policies established by the government has not received any public scrutiny or criticism. Although not all public objections can thwart government policies, some of them are forced to experience some delays due to strong resistance from the community. This is certainly a positive breakthrough in bureaucratic reform. 


\section{CONCLUSION}

From the 1999 to 2019 elections, the challenge of bureaucratic neutrality has never subsided. The dynamics of bureaucratic involvement in elections appear to vary. The 1999 election was recorded as an election that did not involve bureaucracy because the presidential election was conducted by the People's Consultative Assembly. This success cannot be separated from public efforts that keep highlighting the seriousness of the bureaucrats in maintaining their commitment to keep neutral.

The practice of a multi-party system also hampers the creation of a neutral and professional bureaucracy. Even though the New Order has collapsed, it does not mean that improvements to the bureaucracy can be effective. What happened was a change in the bureaucracy from an authoritarian model to a more plural or more opened one. The concept of bureaucratic pluralism extends throughout Indonesia, which is marked by the increasingly influence of social forces on public policy making. The illustration that has appeared during the 1999-2020 period shows: on the one hand Indonesia is moving to a democratic political system, but on the other hand it still faces a strong pull to preserve the patrimonial legacy of the authoritarian regime.

In Indonesia's case, the hope of a simultaneous development between bureaucratic reform and substantive democracy still faces serious challenges. The democratic process that has been going on since 1998, which is expected to improve the quality of the bureaucracy, has not been adequately realized. At the empirical level, the deepening democracy process does not go hand in hand with bureaucratic changes. The big obstacle faced by the bureaucracy is itself, which it is the difficulty of the State Civil Apparatus mind-set and cultural-set.

As a result, the Indonesian bureaucracy is still vulnerable to the intrusion of political power. It is not uncommon for bureaucracy to be used to perpetuate the status quo through its support in national/regional elections. The involvement of the bureaucracy is very prominent in line with the incumbents' participation in the national/regional elections. The tendency to centralise power is fully supported by a bureaucratic system that is not yet fully transparent and accountable (corruption, collusion and nepotism).

The opportunities for future bureaucratic reform may be hampered by a never-ending conflict of interest to always use the bureaucratic machine as a vote collector in elections (either through covert means or implicit statements by state officials). It was evident in the 2019 election. The regional election which was held in 270 regions during the Covid-19 pandemic era even also tended to do the same thing. It prompted the State Civil Apparatus Commission to declare the National Movement for Bureaucratic Neutrality (August 2020) to prevent incumbents from using regional bureaucracy in regional elections.

The inability of the Indonesian bureaucracy to fight opportunistic attitudes and the State Civil Apparatus' mind-set that is still experiencing disorientation and the cultural-set of the bureaucracy that has not changed significantly affects the success or failure of the bureaucracy to maintain its professionalism and neutrality.

\section{REFERENCES}

Asmeron, H. K. \& Reis, E. P. (1996). Introduction. In Haile K. Asmeron and Elisa P. Reis, Democratisation and Bureaucratic Neutrality (pp. 1-19). London: Macmillan Press.

Crouch, H. (1979). Patrimonialism and Military Rule in Indonesia. World Politics, 31(4), 571-587.

Etzioni-Halevi, E. (1986). Bureaucracy and Democracy: A Political Dillema 
(Second Edition). London: Routledge \& Kegan Paul.

Fischer, W. \& Lundgreen, P. (1975). The Recruitment and Training of Administrative and Technical Personnel. In C. Tilly (ed.), The Formation of Nation States in Europe (pp. 456-561). Princeton: Princeton University Press.

Gladden, E. N. (1956). Civil Service or Bureaucracy?. London: Staples Press.

Jackson, K. (1978). Bureaucratic Polity: A Theoretical Framework for the Analysis of Power and Communications in Indonesia. In Karl Jackson and Lucian Pye (eds.), Political Power and Communication in Indonesia (pp. 3-22). Berkeley: University of California Press.

King, D. Y. (1982). Indonesia's New Order as Bureaucratic Polity, a Neopatrimonial Regime, or a Bureaucratic Authoritarian Regime: What Difference Does it Make?. In Anderson and Kahin (eds.), Interpreting Indonesian Politics: Thirteen Contributions to Debate (pp. 104-116). Ithaca: Cornell University.

Kohli, A. \& Shue, V. (1994). State Power and Social Forces: On Political Contention and Accomodation in the Third World. In Joel S. Migdal, Atul Kohli, and Vivienne Shue (ed.), State Power and Social Forces (pp. 293326). Cambridge University Press.

Liddle, W. R.. (1999). Indonesia's Democratic Opening. Government and Opposition, 34(1), 94-116.

MacIntyre, A. (1994). Organising Interests: Corporatism in Indonesian Politics. Working Paper No. 43. The Asia Research Centre Murdoch University.
Migdal, J. S. (1994). The State in Society: An Approach to Struggles for Domination. In Joel S. Migdal, Atul Kohli, and Vivienne Shue (ed.), State Power and Social Forces (pp. 7-34). Cambridge University Press.

Mishra, S. (2002). History in the Making: Systemic Transition in Indonesia. Journal of the Asia Pacific Economy, 7(1), 1-19.

Peraturan Pemerintah Republik Indonesia No.12 Tahun 1999 tentang Perubahan atas Peraturan Pemerintah No. 5 Tahun 1999 tentang Pegawai Negeri Sipil Yang Menjadi Anggota Partai Politik.

Sucipto, R. H. Infrastruktur dan faktor legal masih hambat investasi. (2018, March 30). Republika. Retrieved from https://www.republika.co.id/berita/eko nomi/korporasi/18/03/30/p6dpzu380infrastruktur-dan-faktor-legal-masihhambat-investasi.

Undang-Undang No. 5 Tahun 2014 tentang Aparatur Sipil Negara.

Weber, M. (1947). The Theory of Social and Economic Organisation. New York: The Free Press.

Zuhro, R. S. (1997). Negara, Parpol dan Korpri: Studi Kasus Surabaya. In Muridan Satriyo Wijoyo (ed.), Politisasi / Birokrasi: Implikasi Kebijakan Monoloyalitas Pegawai Negeri Sipil (pp. 45-71). Jakarta: PPWLIPI.

Zuhro, R. S. (2002). Continuity and Change in the Indonesian Bureaucracy since 1998: The Struggle for Democratisation. In Penny O'Connor and Jane Scoot (ed.), Undisciplined Thoughts (pp. 157-168). Perth: Black and Swan. 
Zuhro, R. S. (2003). The Significance of the Neutrality Movement for the Bureaucracy in the 1999 Indonesian Election. In Janis Haswell and Diana MacCallum (Ed.), Liveable Communities (pp. 155-165). Perth: Black and Swan.

Zuhro, R. S. (2005). The Role of the Indonesian Bureaucracy in the Transition Era: The Struggle for Democratisation. West Australia: Curtin University.

Zuhro, R. S. (2019c). Demokrasi dan Pemilu Presiden 2019. Jurnal Penelitian Politik, 16(1), 69-81.

Zuhro, R. S. Pemilu serentak 2019. (2018, July 30). Kompas. Retrieved from https://kompas.id/baca/opini/2018/07/ 30/pemilu-serentak-2019-2/.

Zuhro, R. S. Pilpres milik kita. (2019b, April 17). Kompas. Retrieved from https://kompas.id/baca/opini/2019/04/ 17/pilpres-milik-kita/.

Zuhro, R. S. Politik 2018 dan Pilpres 2019. (2019a, January 2). Kompas. Retrieved from

https://kompas.id/baca/utama/2019/01 /02/politik-2018-dan-pilpres-2019/.

Zuhro, R. Siti (Ed.), 2007. Profesionalitas dan Netralitas Birokrasi untuk Daya Saing Lokal. Jakarta: PT THC Mandiri. 
